
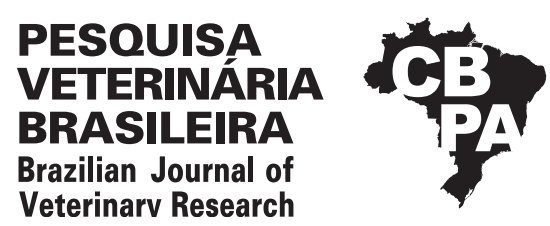

Pesq. Vet. Bras. 40(2):97-101, February 2020 DOI: 10.1590/1678-5150-PVB-6355

Veterinarv Research

ISSN 0100-736X (Print)

ISSN 1678-5150 (Online)

\title{
Influence of organic chromium supplementation on the performance of beef calves undergoing weaning-related stress ${ }^{1}$
}

\author{
Isadora K.F. Sousa ${ }^{2}$ (D), Rejane S. Sousa², Clara S. Mori², Adriana C. Morini', \\ Kedson A.L. Neves ${ }^{3}$, Antonio H.H. Minervino ${ }^{3}$ and Enrico L. Ortolani ${ }^{2 *}$
}

\begin{abstract}
Sousa I.K.F., Sousa R.S., Mori C.S., Morini A.C., Neves K.A.L., Minervino A.H.H. \& Ortolani E.L. 2020. Influence of organic chromium supplementation on the performance of beef calves undergoing weaning-related stress. Pesquisa Veterinária Brasileira 40(2)97-101. Departamento de Clínica Médica, Faculdade de Medicina Veterinária e Zootecnia, Universidade de São Paulo, Butantã, São Paulo, SP 05508-270, Brazil. E-mail: ortolani@usp.br

Dietary chromium supplementation before, during, and after weaning was conducted to evaluate the hypothesis that chromium supplementation could reduce weaning-induced cortisol release in beef calves. We examined the effects of chromium supplementation in 150 crossbred calves (male and female) between five and six months of age. The calves were randomly divided by sex and breed into two equal homogeneous groups $(n=75)$. One group was used as the control, and the other experimental group received supplementation with $0.9 \mathrm{mg}$ of chromium carbon-amino-phospho-chelate per $100 \mathrm{~kg} \mathrm{BW}$. The chromium supplement was mixed with mineral salt for the consumption of $0.1 \%$ of BW, and the supplement was administered via creep feeding 60 days before and 60 days after forced weaning. Calves were weighed, and their blood and urine samples were obtained at four time-points: T0 (60 days before weaning), T1 (at weaning), T2 (48 hours after weaning), and T3 (60 days after weaning). Blood samples were used to determine chromium, cortisol, total protein, and albumin concentrations, and urine samples were used to determine urinary creatinine and chromium levels. Cumulative weight gain was higher in calves supplemented with chromium before weaning and during the experiment $(\mathrm{P}<0.05)$. In addition, weaning-related stress caused an increase in chromium excretion in the urine, and chromium supplementation reduced stress, which resulted in lower cortisol and total protein levels during weaning.
\end{abstract}

INDEX TERMS: Organic chromium, supplementation, beef calves, weaning stress, cattle, performance, stress, mineral supplementation, chromium.

RESUMO.- [Influência da suplementação com cromo orgânico no desempenho de bezerros de corte submetidos ao estresse da desmama.] 0 estudo foi realizado para avaliar a hipótese de que a suplementação dietética com cromo antes, durante e após a desmama possa diminuir a concentração de cortisol causado por este processo em bezerros de corte. Para tal, foram utilizados 150 bezerros mestiços, machos e fêmeas, entre cinco e seis meses de

\footnotetext{
${ }^{1}$ Received on July 19, 2019.

Accepted for publication on August 30, 2019.

${ }^{2}$ Departamento de Clínica Médica, Faculdade de Medicina Veterinária e Zootecnia, Universidade de São Paulo (USP), Butantã, São Paulo, SP 05508-270, Brazil. *Corresponding author: ortolani@usp.br

${ }^{3}$ Laboratório de Sanidade Animal (Larsana), Universidade Federal do Oeste do Pará (UFOPA), Unidade Tapajós, Rua Vera Paz s/n, Bairro Salé, Santarém, PA 68035-110, Brazil.
}

idade. Os animais foram divididos randomicamente por sexo e grupo genético em dois grupos homogêneos ( $n=75)$, um mantido como controle e outro suplementado com $0,9 \mathrm{mg}$ de carboaminofosfoquelato de cromo/100 kg PV misturado a um sal proteinado para ser consumido na base de $0,1 \%$ do PV via creep feeding, no decorrer de 60 dias antes e 60 dias após à desmama forçada. Os animais foram pesados e foram coletadas amostras sanguíneas e urinárias no M0 (60 dias antes da desmama), M1 (desmama), M2 (48 horas após a desmama) e M3 (60 dias após à desmama) para determinação de cromo, cortisol, proteína total e albumina no sangue e da concentração urinária de creatinina e cromo. 0 ganho acumulado de peso foi superior nos bezerros suplementados com cromo antes da desmama e no decorrer de todo o experimento $(\mathrm{P}<0,05)$. A suplementação com cromo reduziu 
os teores de cortisol e de proteína total durante a desmama. O estresse da desmama provocou aumento da excreção de cromo pela urina.

TERMOS DE INDEXAÇ̃̃O: Suplementação, cromo orgânico, bezerros de corte, estresse da desmama, bovinos, desempenho, estresse, suplementação mineral, desmama.

\section{INTRODUCTION}

During weaning, calves are exposed to several stressful factors, including separation from the mother, limited udder access, milk deprivation, and changes to their physical and social environment (Newberry \& Swanson 2008, Weary et al. 2008). In addition to the modification of normal physiological mechanisms in cattle, stress can lead to increases in disease susceptibility (Enriquez et al. 2011), plasmatic cortisol levels (Lay et al. 1998), and concentrations of acute phase proteins (Carroll et al. 2009).

When exposed to severe stress conditions, rats and humans exhibit significantly increased urinary chromium excretion (Anderson 1987). Although strong evidence suggests that this phenomenon also occurs in cattle, the hypothesis still needs to be tested. To date, there are no established chromium requirements for ruminants; however, previous studies have shown that chromium requirements increase under stressful conditions (Underwood \& Suttle 1999). The creep feeding system provides specific mineral supplementation to calves, including chromium (Cr) supplementation (Burton et al. 1994, Wright et al. 1995, Gudev et al. 2007, Yanchev et al. 2008), in addition to favoring contact with solid food prior to weaning progressively reduced the nutritional and social dependency of calves (Weary et al. 2008, Enriquez et al. 2011).

Several studies have also shown that chromium supplementation under stressful conditions exerted a positive effect on productive performance and overall health status. In addition, it also helped to improve the immune response, and this was observed following vaccination in cattle (Faldyna et al. 2003, Pechova \& Pavlata 2007, Montemor \& Marçal 2009, Kumar et al. 2013). Therefore, increased interest in using chromium as a dietary supplement for beef calves is justified by the possible stimulatory effect on their growth rates and immune responses (Chang \& Mowat 1992, Moonsie-Shageer \& Mowat 1993, Depew et al. 1998, Kumar et al. 2013).

The present study aimed to verify the effect of dietary chromium supplementation on cattle performance during pre- and post-weaning periods, and it also sought to evaluate the relationship between weaning-induced stress and urinary chromium excretion.

\section{MATERIALS AND METHODS}

A total of 150 Nelore crossbred calves were analyzed in this study, and the calves were randomly divided by sex, genetic group, and weight into two experimental groups (75 nursing calves in each group). During the 120-day experiment, calves were kept in paddocks containing Brachiaria brizantha and Panicum maximum grass, and they were given access to creep feeding troughs. The calves were weighed at the beginning of the experiment T0 (60 days before weaning), T1 (at weaning) and T3 (60 days after weaning). All weighing was conducted after 16 hours of fasting.
The control group received a protein-salt supplement, which included $20 \%$ raw protein and an increased amount of essential macro-and microelements as compared to chromium. The treatment group received the same diet, with a $30 \mathrm{mg}$ chromium carbon-amino-phospho-chelate (as $\mathrm{Cr}^{+3}$ )/kg dry mass (DM) supplement. In both groups, each supplement was offered so that the average daily consumption per calf was $0.1 \%$ of the body weight (BW) (adjusted based on the animal's weight). The protein salt was formulated with $63 \%$ corn bran and $37 \%$ soy bran, to which $30 \%$ mineral supplement was added. This provided $1.17-2.45 \mathrm{mg} \mathrm{Cr} /$ animal/day to the smallest and largest calves, respectively. Moreover, this amount met the Nutritional Requirement Criteria (NRC 2000) for beef cattle, which state that the chromium concentration should range between 0.6 and $0.75 \mathrm{mg} \mathrm{Cr} /$ animal/day. Grass samples were collected from paddocks throughout the experiment to determine the chromium levels, which varied from 0.05 to $0.12 \mathrm{ppm}$ (average of $0.08 \mathrm{ppm}$.).

The weighing was conducted in corrals, which separated calves from the rest of the cattle. The calves were separated into two different compartments based on the experimental group, and each animal was provided a social space of $10 \mathrm{~m}^{2}$. During the $48-\mathrm{hr}$ weaning period, water and protein salt were provided ad libitum. Weaned calves, separated from their mothers, were then returned to the paddocks until the end of the experiment ( 60 days after weaning).

During all time points (T0, T1, T2 (48 hours after weaning), and T3), blood samples were collected from calves in tubes without anticoagulants (BD Vacutainer ${ }^{\circledR}$, New Jersey, EUA). Analyses of serum samples were conducted to determine concentrations of total protein, albumin, cortisol, and chromium. Biochemical analyses were carried out in a Daytona RX (Randox ${ }^{\circledR}$, Antrin, UK) automatic biochemical analyzer, using specific kits (Randox ${ }^{\circledR}$, Antrin, UK) for each variable. The determination of cortisol concentrations was performed using a chemiluminescent assay kit (Siemens ${ }^{\circledR}$, Munich, Germany) in an immunoassay analyzer (Immulite 1000, Siemens ${ }^{\circledR}$, Munich, Germany).

Urine samples were collected at the four time-points during the experiment, after manual stimulation of the vulva or foreskin. The sample were centrifuged and the supernatant stored in microtubes and frozen at $-20^{\circ} \mathrm{C}$ until analysis. Samples were analyzed to determine chromium and creatinine ( $\mathrm{Crt}$ ) concentrations. The urine creatinine were determined in equipment Daytona RX (Randox ${ }^{\circledR}$, Antrin, UK), using kit Randox ${ }^{\circledR}$. The resulting calculations and the metabolic weight (live weight $\mathrm{t}^{0.75}$ ) of each animal were used to calculate the chromium urinary secretion rate (CrUSR), which corresponds to the secreted amount of chromium in the urine (CrU) (corrected by urinary Crt and metabolic weight). This value was calculated following the recommendations of Fleming et al. (1991) and Soares (2004).

Serum and urine also samples were used to determine chromium concentration via digestion with chromium-free nitric acid and perchloric acid solutions ( $4: 1 \mathrm{v} / \mathrm{v}$ ), which were analyzed using optical spectrophotometry by plasma emission (Varian ${ }^{\circledR}$, Saint Claire, USA) (Minervino et al. 2018).

Statistical analyses were performed with the aid of the SAS statistical software (SAS 2009). The normal distribution of the data was assessed by the Shapiro-Wilk test, and data that followed a parametric distribution were subjected to an analysis of variance using the PROC MIXED procedure for repeated measurements over time. The effects of treatment, time, and the interaction between treatment and time were examined for each variable. Data that did not follow a parametric distribution were subjected to the Mann-Whitney test, and median values were reported. The correlation and determination coefficients were calculated to determine the correlation between two variables. A P-value equal to or lower than $5 \%$ was considered significant for all statistical tests. 


\section{RESULTS AND DISCUSSION}

Compared to control animals, chromium-supplemented calves exhibited greater accumulated weight gain 120 days after the beginning of the experiment $(\mathrm{P}=0.037)$, and an average gain of $6.5 \mathrm{~kg}$ was observed in treated animals. This effect of chromium on the accumulated weight gain was verified during the weaning period (T0-T1, $\mathrm{P}=0.006$ ), and there was no significant difference between groups when the weight gain during the post-weaning period (T1-T3) was considered (Table 1).

The relationship between chromium and animal production is controversial, because different studies indicated that no relationship exists between chromium supplementation and increased body weight in ruminants (Chang \& Mowat 1992, Zanetti et al. 2003, Pechova \& Pavlata 2007, Yanchev et al. 2008, Kumar et al. 2013). However, the methodology and analysis employed in the present study are likely factors that contributed to the positive results obtained. For instance, most studies assessed BW data and daily weight gain, which are typically heterogeneous because of the individual characteristics of animals. In the present study, the accumulated weight gain was defined as the amount (in $\mathrm{kg}$ ) that each animal gained during a given period, and the use of this parameter negated the effects associated with the variability of BW. In addition, the large number of animals employed in this study and the use of timed artificial insemination (TAI) generated animal consignments resulted in greater homogeneity between groups.
In contrast to most studies, which did not correlate chromium supplementation to enhanced productive performance, this study provided the mineral to calves before the occurrence of an acute stress event (60 days prior). The factors associated with increased accumulated weight gain in supplemented animals were associated with lower stress, reduced fighting, and frequent visits to the trough. Among animals with limited stress, the benefits of chromium supplementation would not correspond to enhanced productive gain (Zanetti et al. 2003).

The mean chromium serum concentrations in supplemented and non-supplemented animals are shown in Table 3. Chromium levels in serum were expected to significantly increase in response to supplementation, but there were no differences between the treated and control groups. Despite the fact that excessive chromium levels in the blood correlate to toxic levels, few cattle studies have assessed chromium levels in the blood, which may vary based on the amount of chromium in the food (e.g., 57.7-1,769.0nM) (Pechova \& Pavlata 2007, Tomza-Marciniak et al. 2011). The chromium levels in blood values found in this study were within the indicated interval and were non-toxic. The results of a recent study indicated that the concentration of chromium in serum significantly increased when calves were supplemented with a diet containing high levels of chromium ( $\geq 4 \mathrm{mg} /$ day) (Kumar et al. 2013). In the present study, calves ingested an estimated maximum of $2.5 \mathrm{mg} \mathrm{Cr} /$ day, which did not interfere with the

Table 1. Accumulated weight gain $(\mathrm{kg})$ of the calves during the experiment

\begin{tabular}{|c|c|c|c|c|c|}
\hline \multirow{2}{*}{ Time point } & \multicolumn{2}{|c|}{ Control group } & \multicolumn{2}{|c|}{ Treatment group } & \multirow{2}{*}{$\mathrm{P}$} \\
\hline & Mean & SD & Mean & SD & \\
\hline T1-T0 & $54.5^{\text {в }}$ & 13.9 & $60.1^{A}$ & 11.7 & 0.006 \\
\hline T3-T1 & 14.9 & 8.0 & 15.8 & 5.2 & 0.464 \\
\hline T3-T0 & $68.1^{\mathrm{B}}$ & 17.3 & $74.6^{\mathrm{A}}$ & 14.7 & 0.037 \\
\hline
\end{tabular}

$\overline{\mathrm{A}, \mathrm{B}}$ Uppercase letters in the column indicate differences between groups, and lowercase letters indicate differences between time points.

Table 2. Urinary chromium excretion rate (nM) in control and treated calves assessed at different time points

\begin{tabular}{cccc}
\hline \multirow{2}{*}{ Time point } & Control group & Treatment group & Median \\
\cline { 2 - 3 } & Median & $2.14^{\mathrm{b}}$ & 0.5725 \\
T0 & $1.93^{\mathrm{b}}$ & $10.93^{\mathrm{a}^{*}}$ & 0.3254 \\
T2 & $14.00^{\mathrm{a}}$ & $19.28^{\mathrm{a}^{*}}$ & 0.0735 \\
$\mathrm{P}$ & $9.24^{\mathrm{a}}$ & 0.0218 & \\
\hline
\end{tabular}

$\overline{\mathrm{a}, \mathrm{b}}$ Lowercase letters indicate differences between time points based on the Mann-Whitney test.

Table 3. Average concentration and standard deviation of serum and urinary chromium (Cr, nM), cortisol (nM), and total protein $(\mathrm{Pt}, \mathrm{g} / \mathrm{dL})$ in control and treated calves assessed at different time points

\begin{tabular}{|c|c|c|c|c|c|}
\hline \multirow{2}{*}{ Variable } & \multirow{2}{*}{ Group } & \multicolumn{4}{|c|}{ Time point } \\
\hline & & T0 & $\mathrm{T} 1$ & $\mathrm{~T} 2$ & T3 \\
\hline \multirow[t]{2}{*}{ Serum Cr (nM) } & Control & $257.3 \pm 90.2$ & $216.9 \pm 49.9$ & - & $257.3 \pm 94.1$ \\
\hline & Treatment & $222.7 \pm 78.7$ & $222.5 \pm 57.6$ & - & $266.9 \pm 113.3$ \\
\hline \multirow[t]{2}{*}{ Urinary Cr (nM) } & Control & $192.2 \pm 123.4^{c}$ & $238.1 \pm 92.9^{c}$ & $443.1 \pm 148.2^{\mathrm{a}}$ & $316.8 \pm 147.2^{b}$ \\
\hline & Treatment & $228.2 \pm 104.2^{c}$ & $185.6 \pm 91.6^{c}$ & $379.0 \pm 131.7^{a}$ & $333.1 \pm 142.4^{b}$ \\
\hline \multirow[t]{2}{*}{ Cortisol (nM) } & Control & $64.03 \pm 21.25^{b}$ & $110.4 \pm 41.44^{\mathrm{a}}$ & $76.45 \pm 28.98^{\mathrm{Ab}}$ & $98.25 \pm 36.43^{a}$ \\
\hline & Treatment & $66.79 \pm 3.03^{b}$ & $99.63 \pm 4.69^{\mathrm{a}}$ & $63.73 \pm 3.03^{\mathrm{Bb}}$ & $106.53 \pm 5.79^{a}$ \\
\hline \multirow[t]{2}{*}{$\operatorname{Pt}(\mathrm{g} / \mathrm{dL})$} & Control & $69.0 \pm 4.2^{c}$ & $70.4 \pm 4.1^{\mathrm{Aa}}$ & $69.5 \pm 4.7^{b}$ & $69.6 \pm 5.3^{\mathrm{Bb}}$ \\
\hline & Treatment & $69.2 \pm 6.6^{b}$ & $68.8 \pm 4.5^{\mathrm{Bb}}$ & $68.3 \pm 4.3^{\mathrm{b}}$ & $71.4 \pm 5.0^{\mathrm{Aa}}$ \\
\hline
\end{tabular}

$\overline{\mathrm{A}, \mathrm{B}}$ Uppercase letters in the column indicate differences between groups, ${ }^{\mathrm{a}, \mathrm{b}, \mathrm{c}}$ lowercase letters indicate differences between time points. 
serum concentration. Furthermore, the results of this study did not corroborate the conclusion proposed by Pechova \& Pavlata (2007), which stated that serum concentrations were poor indicators of chromium status in normal cattle.

Several studies in humans have shown that various forms of stress led to increased urinary chromium excretion that could be up to 10 times higher than normal (Pechova \& Pavlata 2007). However, there are no studies in ruminants that report increased urinary chromium excretion under stressful conditions. The results of this study show an increase in the urinary chromium excretion rate at peak stress levels (T2) relative to the $\mathrm{T} 0$ time point, and these levels ranged from $380 \%$ to $800 \%$ in the control and supplemented groups, respectively (Table 2). By examining this variable, it was possible to determine that dietary chromium supplementation tended to increase this index $(\mathrm{P}=0.0791)$ (Table 2) relative to the control group, which suggests that chromium is lost from its organic reserves in calves under stressful conditions.

When creatinine levels were not used to appropriately correct the urinary chromium levels, no differences in urinary chromium levels were detected between the supplemented and the control groups (Table 3). However, the levels varied in relation to the time points in that levels were higher in $\mathrm{T} 2$ as compared to $\mathrm{T} 3$, and both values were higher when compared to T0 $(\mathrm{P}<0.05)$ for the supplemented and control groups. These results highlighted the fact that the excretion rate was more effective and accurate when assessing urinary chromium levels, following proper adjustment with urinary creatinine data. In fact, many animals under stress become more dehydrated and urinate less, which results in concentrated urine that could mask the results.

Lower levels of cortisol were detected in animals supplemented with chromium at $\mathrm{T} 2$ relative to controls, and the time point analysis within each group indicated that cortisol was greater at $\mathrm{T} 1$ and $\mathrm{T} 3$ relative to the values obtained at T0 and T2 (Table 3). This result suggested that under stressful conditions, chromium diminished excessive cortisol excretion, which causes metabolic disorders in animals. Similar results were previously described in a study where chromium was added to cattle diets (Chang \& Mowat 1992, Mowat et al. 1993, Yanchev et al. 2008, Kumar et al. 2013).

Relative to the control group, lower and higher concentrations of total protein were detected in the supplemented group at T1 and T3, respectively. Within the control group, higher protein concentrations were found at $\mathrm{T} 1$, followed by $\mathrm{T} 2$ and $\mathrm{T} 3$, and these concentrations were greater than those detected at $\mathrm{T} 0$. In the supplemented group, the highest protein level was detected at T3 (Table 3). The analysis did not detect a positive correlation $(\mathrm{r}=0.196)$ between albumin and serum protein levels in the control group at T1. Considering that the serum protein level at this time point was higher than levels at the other time points for this group, we might speculate that the protein increase was triggered by the presence of acute phase proteins. This hypothesis is based on the fact that weaning-mediated stress causes an immediate increase in the level of acute phase proteins in blood; however, this aspect was not addressed in this study (Wright et al. 1995, Carroll et al. 2009).

The supplemented group displayed a greater concentration of total protein and serum albumin as compared to the control group at T3 (Table 3). An analysis of these variables at T3 indicated a positive correlation ( $\mathrm{r}=0.611)$, which suggested that increased total protein at this time point was due to increased albumin levels that indicated protein synthesis in the organism (Kaneko et al. 2008).

\section{CONCLUSIONS}

The chromium supplementation promoted greater accumulated weight gain in calves before weaning and during the experiment, reduced levels of cortisol and serum protein and diminished urinary chromium excretion rates during weaning were detected.

Continuous and prolonged supplementation of organic chromium in beef calves reduced weaning-related stress.

Ethics Committee.- This study was approved by the Ethics Committee in Animal Experimentation of the "Faculdade de Medicina Veterinária e Zootecnia" of the "Universidade de São Paulo" (CEUA-FMVZ-USP) under protocol number $2429 / 2011$.

Acknowledgments.- The authors thank the Research Foundation of São Paulo ("Fundação de Amparo à Pesquisa de São Paulo" - FAPESP) (Reference number 2012/10014-6) for financial support.

Conflict of interest statement.- We have no conflict of interest to declare.

\section{REFERENCES}

Anderson R.A. 1987. Chromium, p.225-244. In: Mertz W. (Ed.), Trace Elements in Human and Animal Nutrition. Vol.1. Academic Press, New York. <http:// dx.doi.org/10.1016/B978-0-08-092468-7.50011-9>

Burton J.L., Mallard B.A. \& Mowat D.N. 1994. Effects of supplemental chromium on antibody responses of newly weaned feedlot calves to immunization with infections bovine rhinotracheitis and parainfluenza 3 virus. Can. J. Vet. Res. 58(2):148-151. <PMid:8004541>

Carroll J.A., Arthington J.D. \& Chase Jr C.C. 2009. Early weaning alters the acute phase reaction to an endotoxin challenge in beef calves. J. Anim. Sci. 87(12):2009-2016. <http://dx.doi.org/10.2527/jas.2009-2016> <PMid:19717781>

Chang X. \& Mowat D.N. 1992. Supplemental chromium for stressed and growing feeder calves. J. Anim. Sci. 70(2):559-565. <http://dx.doi. org/10.2527/1992.702559x> <PMid:1548220>

Depew C.L., Bunting L.D., Fernandez J.M., Thompson Jr D.L. \& Adkinson R.W. 1998. Performance and metabolic responses of young dairy calves fed diets supplemented with chromium tripicolinate. J. Dairy Sci. 81(11):2916-2923. <http://dx.doi.org/10.3168/jds.S0022-0302(98)75853-9> <PMid:9839235>

Enriquez D., Hotzel M.J. \& Ungerfeld R. 2011. Minimising the stress of weaning of beef calves: A review. Acta Vet. Scand. 53(1):28. <http://dx.doi. org/10.1186/1751-0147-53-28> <PMid:21569479>

Faldyna M., Pechova A. \& Krejci J. 2003. Chromium supplementation enhances antibody response to vaccination with tetanus toxoid in cattle. J. Vet. Med. B. Infect. Dis. Public Health 50(7):326-331. <PMid:14535930>

Fleming S.A., Hunt E.L., Riviere J.E. \& Anderson K.L. 1991. Renal clearence and fractional excretion of electrolytes over four 6-hour periods in cattle. Am. J. Vet. Res. 52(1):5-8. <PMid:2021253>

Gudev D., Ralcheva I., Yanchev P., Moneva P., Peeva T., Penchev P. \& Ilieva I. 2007. Effect of weaning on some plasma metabolites in buffalo calves fed diets with or without supplemental chromium picolinate. Ital. J. Anim. Sci. 6(2):547-550. <http://dx.doi.org/10.4081/ijas.2007.s2.547>

Kaneko J.J., Harvey J.W. \& Bruss M.L. 2008. Clinical Biochemistry of Domestic Animals. 6th ed. Elsevier, San Diego. 
Kumar M., Kaur H., Tyagi A.K., Kewalramani N.J., Mani V., Deka R.S., Sharma V.K., Chandra G. \& Dang A.K. 2013. Effect of feeding inorganic chromium on growth performance, endocrine variables, and energy metabolites in winter-exposed buffalo calves (Bubalus bubalis). Biol. Trace Elem. Res. 155(3):352-360. <http://dx.doi.org/10.1007/s12011-013-9808-3> $<$ PMid:24013931>

Lay Jr D.C., Friend T.H., Randel R.D., Bowers C.L., Grissom K.K., Neuendorff D.A. \& Jenkins O.C. 1998. Effects of restricted nursing on physiological and behavioral reactions of Brahman calves to subsequent restraint and weaning. Appl. Anim. Behav. Sci. 56(2):109-119.<http://dx.doi.org/10.1016/ S0168-1591(97)00103-2>

Minervino A.H.H., López-Alonso M., Barrêto Júnior R.A., Rodrigues F.A.M.L., Araújo C.A.S.C., Sousa R.S., Mori C.S., Miranda M., Oliveira F.L.C., Antonelli A.C. \& Ortolani E.L. 2018. Dietary zinc supplementation to prevent chronic copper poisoning in sheep. Animals 8(12):227. <http://dx.doi.org/10.3390/ ani8120227><PMid:30513571>

Montemor C.H. \& Marçal W.S. 2009. The performace of nelore steers supplemented with organic chromium. Semina, Ciênc. Agrárias 30(3):701-708.

Moonsie-Shageer S. \& Mowat D.N. 1993. Effect of level of supplemental chromium on performance serum constituents, and immune of stressed feeder calves. J. Anim Sci. 71(1):232-238. <http://dx.doi.org/10.2527/1993.711232x> $<$ PMid:8454546>

Mowat D.N., Chang X. \& Yang W.Z. 1993. Chelated chromium for stressed feeder calves. Can. J. Anim. Sci. 73(1):49-55. <http://dx.doi.org/10.4141/ cjas93-004>

Newberry R.C. \& Swanson J.C. 2008. Implications of breaking motheryoung social bonds. Appl. Anim. Behav. Sci. 110(1):3-23. <http://dx.doi. org/10.1016/j.applanim.2007.03.021>

NRC 2000. Nutrient requirements of beef cattle: minerals. 7 th ed. National Research Council, National Academic Press, Washington. 577p.
Pechova A. \& Pavlata L. 2007. Chromium as an essential nutrient: a review. Vet. Med. 52(1):1-18. <http://dx.doi.org/10.17221/2010-VETMED>

SAS 2009. SAS user's guide: statistics. SAS Institute, Cary.

Soares P.C. 2004. Effects of copper poisoning and its treatment with tetrathiomolybdate on renal function oxidative metabolismo in lambs. Doctoral Dissertation, Universidade de São Paulo, São Paulo. 116p.

Tomza-Marciniak A., Pilarczyk B., Bakowska M., Pilarczyk R. \& Wójcik J. 2011. Heavy metals and other elemensts in serum of cattle from organic and conventional farms. Biol. Trace Elem. Res. 143(2):863-870. <http:// dx.doi.org/10.1007/s12011-010-8910-z><PMid:21113686>

Underwood E.J. \& Suttle N.F. 1999. The mineral nutrition of livestock. 3rd ed. Cabi Publishing, Wallingford. 614p. <http://dx.doi.org/10.1079/978 0851991283.0000>.

Weary D.M., Jasper J. \& Hötzel M. 2008. Understanding weaning distress. Appl. Anim. Behav. Sci. 110(1):24-41. <http://dx.doi.org/10.1016/j. applanim.2007.03.025>

Wright A.J., Mallard B.A. \& Mowat D.N. 1995. The influence of supplemental chromium and vaccines on the acute phase response of newly arrived feeder calves. Can. J. Vet. Res. 59(4):311-315. <PMid:8548694>

Yanchev I., Moneva P., Gudev D., Popova-Ralcheva S., Peeva T., Penchev P. \& Ilieva I. 2008. Effect of weaning on some plasma metabolites in black-andwhite calves fed diets with or without supplemental chromium picolinate. Bulg. J. Agric. Sci. 14(3):329-334.

Zanetti M.A., Salles M.S.V., Brisola M.L. \& César M.C. 2003. Performance and metabolic response of calves fed diets supplemented with chromium. Revta Bras. Zootec. 32:1532-1535. <http://dx.doi.org/10.1590/S151635982003000600030> 